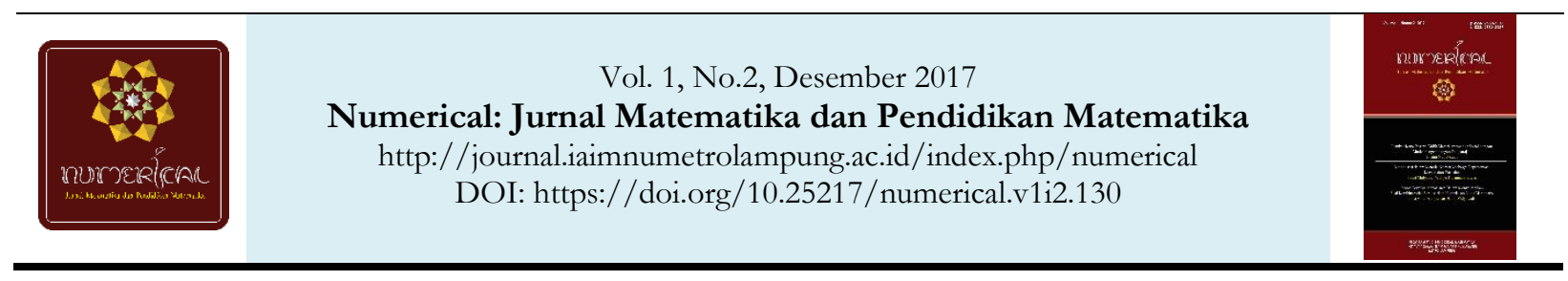

\title{
Analisis Unsur Matematika pada Motif Sulam Usus
}

\author{
Leni Zuni Isnawati ${ }^{1}$, Fredi Ganda Putra ${ }^{2}$
}

1,2) Universitas Islam Negeri Raden Intan Lampung, Indonesia

Correspondence: $\$ Lenizuli682i@gmail.com

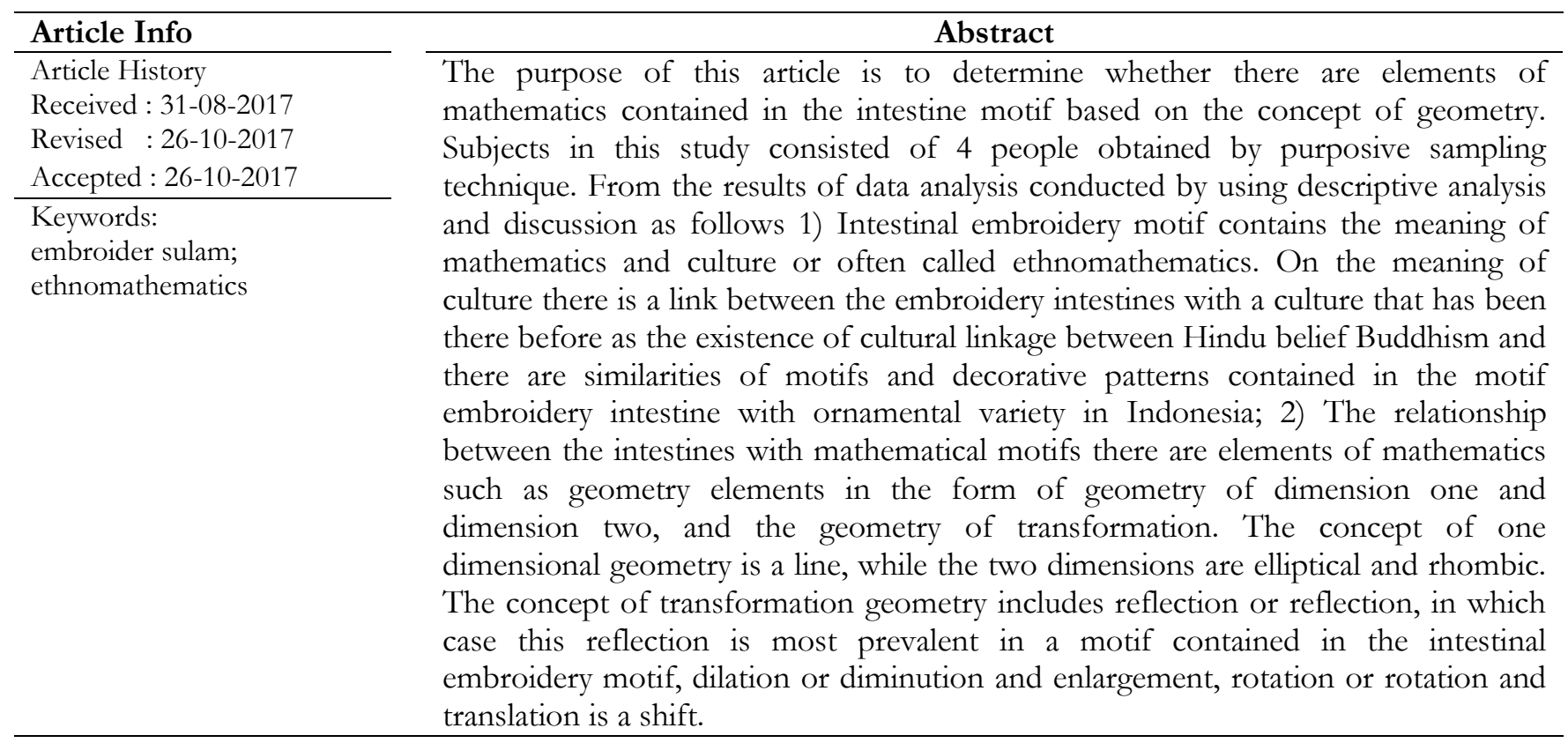

\section{PENDAHULUAN}

Indonesia merupakan sebuah negara kepulauan, dengan beraneka ragam suku dan budaya yang dimiliki dari ujung barat sampai ujung timur yang menandakan dari Sabang sampai Merauke, yang memiliki adat istiadat dan budaya daerah yang beragam. Keberagaman budaya itu dipengaruhi oleh berbagai macam faktor, faktor tersebut diantaranya yaitu letak geografis, mata pencaharian, pola hidup, pola bercocok tanam dan kepercayaan yang dianut oleh daerah tersebut. Faktor-faktor tersebut melahirkan sebuah keberagaman budaya, adat-istiadat, bahasa daerah, rumah adat, dan terdapat pula busana atau pakaian tradisional daerah serta produk-produk hasil kebudayaan lainya. Busana tradisional sebagai salah satu produk hasil kebudayaan juga memiliki keberagaman yang terdapat pada motif, bentuk, warna dan coraknya. Sehingga, antara daerah yang satu dengan yang lainya memiliki persamaan dan perbedaan yang menjadi ciri khas daerahannya, hal ini dapat terlihat dari hasil produksi yang dimiliki setiap daerah yang menandakan beranekaragamnya aktivitas etnomatematika di dalamnya, tidak terkecuali dengan Lampung, dimana di daerah Lampung ini terdapat berbagai macam budaya yang berkembang pesat dan berdampingan erat dengan masyarakat serta aktivitas etnomatematika dalam kehidupan sehari-hari. Seperti halnya tarian khas Lampung, kain khas Lampung, kerajinan tangan dan lain sebagainya. 
Kemajuan suatu kebudayaan bergantung kepada cara kebudayaan tersebut mengenali, menghargai dan memanfaatkan sumber daya manusia. Masyarakat dapat memanfaatkan dan mengolah sumber daya yang dimiliki demi terciptanya sebuah kemajuan dalam kebudayaan, sehingga kebudayaan akan tetap terus berinovasi dengan menciptakan hasil budaya baru yang dimiliki oleh masyarakat agar budaya yang dimiliki tetap exis sepanjang masa. Salah satu unsur perubahan budaya adalah hubungan antarbudaya, yang dimaksud dengan hubungan antarbudaya yaitu adanya hubungan budaya lokal dengan budaya asing. Hubungan anatarbudaya berisi konsep akulturasi budaya. Demi terwujudnya kemajuan kebudayaan diperlukan suatu akulturasi budaya.

Akulturasi yaitu memadukan dua kebudayaan atau lebih yang saling mempengaruhi. Dalam akulturasi budaya yang berkembang di dalam masyarakat, akulturasi tersebut hanya saling mempengaruhi satu sama lain saja tanpa menghilangkan ciri khas budaya asli yang dimilikinya. Perpaduan tersebut dapat dikatakan pula perpaduan antara budaya yang sudah ada di dalam masyarakat sejak zaman dahulu dengan budaya saat ini yang selalu berkembang di dalam masyarakat, serta perpaduan antara budaya daerah satu dengan daerah yang lainnya yang saling berkaitan satu dengan yang lainnya, serta perpaduan antara budaya dengan matematika atau akulturasi antara budaya dengan matematika. Akulturasi budaya dengan matematika dapat terlihat dari aktivitas manusia sehari-hari yang di lakukan di dalam masyarakat, kegiatan tersebut diantaranya yaitu menghitung, mengukur, menilai dan lain sebagainya. Dalam kebudayaan yang berkembang di dalam masyarakat memerlukan kegiatan menghitung, mengukur, menilai dan lain sebagainya agar dalam menyelesaikan persoalan yang terdapat di dalam masyarakat dapat teratasi. Akulturasi budaya dengan matematika dapat disebut juga dengan istilah etnomatematika.

Etnomatematika merupakan hubungan yang menjembatani antara matematika dengan budaya, sebagaimana etnomatematika mengakui adanya cara-cara yang berbeda dalam menerapkan matematika dalam kehidupan atau aktivitas masyarakat [1]. Dalam etnomatematika bukan berarti harus menjadi manusia yang primitif atau kembali pada zaman dahulu kala. Namun bagaimana budaya yang sudah menjadi suatu karakter atau ciri khas asli suatu bangsa dapat terus bertahan dengan disesuaikan pada waktu dan zaman saat ini [2]. Dengan menerapkan etnomatematika akan sangat memungkinkan suatu kegiatan atau masalah yang dipelajari yang terkait dengan budaya mereka, sehingga pemahaman terhadap aplikasi ilmu matematika oleh masyarakat menjadi lebih mudah untuk dipahami, karena kegiatan atau masalah tersebut berkaitan langsung dalam kegiatan budaya mereka yang dilakukan dalam aktivitas kehidupan manusia sehari-hari. Jika dilihat dari peranan etnomatematika dalam kehidupan sehari-hari, tidak dapat dipungkiri bahwa terdapat kaitan antara matematika dengan bidang kebudayaan dan kebiasaan, matematika dalam bidang pendidikan serta matematika dalam bidang adat istiadat [3].

Budaya merupakan keseluruhan sistem gagasan, tindakan dan hasil karya manusia dalam rangka kehidupan masyarakat yang dijadikan milik diri manusia dengan belajar [4]. Hal tersebut dapat diartikan bahwa budaya merupakan suatu tingkah laku cipta karsa ataupun usaha sadar yang dilakukan masyarakat di dalam kehidupan sehari-hari yang menjadikan ciri khas ataupun pembeda antara satu budaya dengan budaya yang lainnya yang tidak dimiliki oleh budaya lain, sehingga hampir seluruh kegiatan yang dilakukan masyarakat dan berkembang dalam masyarakat merupakan suatu budaya karena hanya sedikit sekali tindakan manusia dalam rangka kehidupan masyarakat yang bukan merupakan suatu budaya.

Masyarakat Lampung terdiri dari berbagai etnis yang mencerminkan tipologi masyarakat multikultural. Kebudayaan lokal pun merupakan bagian integrasi yang tidak terpisahkan dari kehidupan 
sehari-hari masyarakatnya. Masyarakat Lampung dan budaya lokal bersenyawa dalam satu-kesatuan yang padu. Kebudayaan menjadi "detak nadi" dalam kehidupan masyarakat, oleh karena itu memisahkan masyarakat Lampung dari kebudayaan mereka adalah mustahil. Masyarakat Lampung adalah masyarakat yang menjunjung tinggi nilai budaya. Masyarakat Lampung sangat mencintai dan melestarikan budaya yang sudah ada sejak nenek moyang dan berkembang seiring berjalannya waktu. Dari kecintaan dan melestarikan masyarakat Lampung terhadap budaya yang dimilikinya terdapat banyak sekali hasil karya serta budaya yang dimiliki masyarakat Lampung seperti halnya tarian adat Lampung, kain khas Lampung, mainan tradisional Lampung, kerajinan tangan serta sulaman yang berkembang di masyarakat Lampung.

Berkaitan tentang sulaman yang berkembang di masyarakat Lampung, kegiatan menyulam sudah dilakukan sejak dahulu kala. Kegiatan menyulam juga terdapat di dalam Al-Quran An-Nahl ayat 92:

"Dan janganlah kamu seperti seorang perempuan yang menguraikan benangnya yang sudah dipintal dengan kuat, menjadi cerai berai kembali. Kamu menjadikan sampah (perjanjian) mu sebagai alat penipu diantara-mu disebabkan adanya satu golongan yang lebih banyak jumlahnya dari golongan yang lain. Allah hanya menguji kamu dengan hal itu, dan pasti pada hari kiamat akan dijelaskann-Nya kepadamu apa yang dabulu kamu perselisibkan itu.'[5]

Dari ayat di atas dijelaskan bahwa pada saat itu sudah terdapat pengetahuan tentang menganyam (menyulam) yang jelas terlihat di dalam kalimat "menguraikan kembali benang yang dipintal dengan kuat", kegiatan menyulam dilakukan dengan cara memintal benang, lalu dilanjutkan dengan tahaptahapan selanjutnya yang lebih signifikan. Tradisi menyulam ditransmisikan secara turun temurun yang diajarkan secara alami.

Sulam usus adalah seni kerajinan sulam warisan nenek moyang suku Lampung Pepadun di daerah Menggala, Kabupaten Tulang Bawang [6]. Sulam usus dibentuk dengan menganyam kain satin yang dibentuk menyerupai usus ayam dengan motif yang khas. Sulam usus dirajut dengan menggunakan benang emas dan nilon. Motif dalam sulam usus adalah motif-motif naturalis, geometris dan nongeometris.

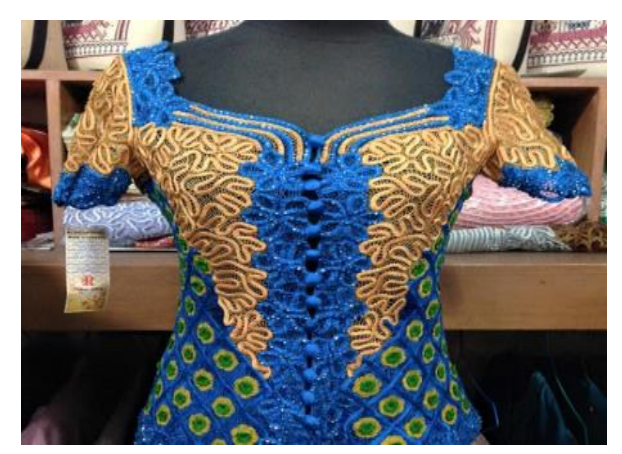

Gambar 1. Kebaya Sulam Usus

Berdasarkan wawancara dengan narasumber menyatakan bahwa awal mulanya sulam usus merupakan sebuah seni kerajinan tangan asli. Disebut sulam usus karena teknik ini merupakan teknik menggabungkan helaian kain yang menyerupai usus yang dibentuk sesuai pola dengan cara disulam menggunakan benang. Teknik sulam usus pada awalnya digunakan untuk membuat penutup bahu pakaian adat wanita Lampung atau sering disebut sebagai bebe. Namun tidak banyak pula masyarakat Lampung khususnya masyarakat yang tinggal di Lampung masih banyak yang belum mengetahui dan mengenal sulam usus karena kebanyakan hanya mengenal tapis saja yang menjadi ciri khas Lampung, 
disamping itu masih terdapat hasil budaya yang lainnya yaitu sulam usus. Dalam sulam usus juga terdapat pengetahuan tentang matematika.

Mempelajari matematika tidak hanya memahami konsepnya saja atau prosedurnya saja, akan tetapi banyak hal yang dapat muncul dari hasil proses pembelajaran matematika [7]. Karena matematika merupakan sarana berpikir logis, kritis, dan kreatif sehingga tidak dapat dipisahkan dari kehidupan manusia [8]. Dalam kaitan dengan pemanfaatan matematika dalam kehidupan, dimana matematika merupakan buman activity, matematika memiliki nilai-nilai penting untuk membantu masyarakat menghadapi berbagai tantangan hidup dalam berbagai problematika yang dihadapinya. Matematika merupakan bagian dari kehidupan manusia. Setiap aktivitas manusia yang terkait dengan matematika mulai dari matematika dalam bentuk yang sederhana hingga matematika yang lebih berkembang menjadi lebih kompleks [9]. Sejak peradaban manusia bermula, manusia telah memiliki peran penting dalam kehidupan sehari-hari. Berbagai bentuk simbol, teorema, rumus, dalil, ketetapan serta konsep digunakan dalam membantu suatu perhitungan, pengukuran, penilaian, geometri, geometri transformasi, dan lain sebagainya. Terkait dengan matematika dan budaya yang telah dibahas sebelumnya, yang tidak dapat dipisahkan satu sama lain, sehingga di dalam prinsip budaya terdapat prinsip pendidikan. Dalam hal ini adalah unsur-unsur matematika yang berkaitaan dengan konsep matematika.

Pembahasan geometri juga tercantum di dalam Al-Quran yang terdapat di dalam surah Ibrahim ayat 33 yang artinya: "Dia telah menundukean (pula) bagimu matahari dan bulan yang terus menerus beredar (dalam orbitnya), dan telah menundukean bagimu malam dan siang".[5]

Dari ayat di atas dijelaskan bahwa terdapat aktifitas geometri yang terdapat di dalam kalimat "beredar (dalam orbitnya)" dalam aktivitas tersebut berarti mengelilingi suatu benda dengan sesuai dengan jalur atau lintasan yang telah ditentukan. Seperti halnya di dalam geometri juga terdapat aktivitas seperti yang telah disebutkan sebelumnya, yang terdapat kaitannya dengan bangun datar yang melingkar yaitu keliling dari bangun tersebut. Geometri adalah cabang ilmu matematika yang mempelajari hubungan antara titik-titik, garis-garis, bidang-bidang serta bangun datar dan bangun ruang[10]. Geometri membahas masalah-masalah yang ada di dalam kehidupan manusia, terlihat dari berbagai bentuk, fenomena alam, serta kegiatan yang kita lakukan yang terdapat di sekeliling kita sebagian besar merupakan hasil dari geometri [11] [12]. Tidak hanya mengenai geometri saja yang membahas masalahmasalah yang ada di dalam kehidupan manusia tetapi juga mengenai geometri transformasi.

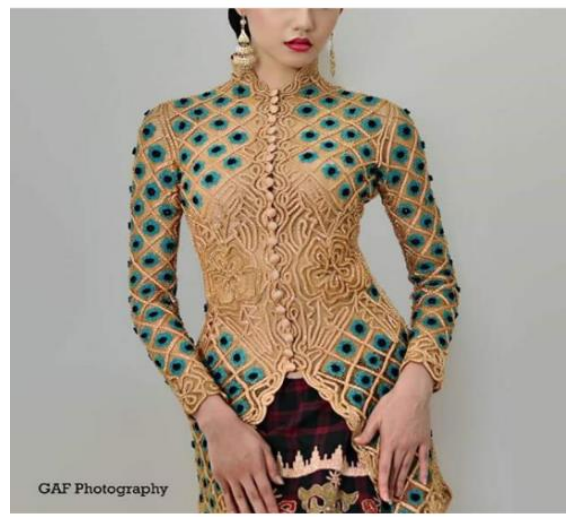

Gambar 2. Kebaya Sulam Usus

Saat ini telah banyak diadakan penelitian tentang etnomatematika yaitu matematika pada kerajinan tenun Suku Sasak Sukarara yang menenkankan pada konsep geometri dan geometri transformasi, pada 
konsep geometri seperti belahketupat dan lain sebagainya sedangkan pada konsep geometri transformasi meliputi translasi, refleksi, rotasi dan dilatasi [13]. Mengacu pada penelitian tersebut bahwa perlu ada inovasi penelitian tentang etnomatematika karena Lampung mempunyai kerajinan tangan yang indah yaitu sulam usus yang di dalamnya dapat digali lebih dalam mengenai unsur ataupun konsep matematika yang terdapat pada motif sulam usus tersebut. Penelitian ini ingin menggali dan mengeksplorasi unsur-unsur dan konsep matematika yang ada di dalam sulam usus tersebut. Berdasarkan latar belakang tersebut, maka dirasa sangat penting untuk diadakan penelitian tentang kaitan antara unsur-unsur matematika dan konsep matematika dalam motif sulam usus, oleh karena itu peneliti tertarik untuk memahami dan mengkaji "Etnomatematika Pada Motif Sulam Usus Dalam Bahasan Geometri”.

\section{METODE}

Penelitian ini menggunakan metode deskriptif kualitatif. Peneliti berusaha menggambarkan secara sistematis fakta dan karakteristik mengenai motif sulam usus secara tepat. Pemilihan subjek dalam penelitian ini menggunakan purposive sampling yaitu penentuan sampel dengan pertimbangan tertentu [14]. Pertimbangan tersebut diambil berdasarkan kepada orang yang dianggap paling tahu mengenai informasi yang peneliti butuhkan sehingga akan memudahkan peneliti dalam menjelajahi objek atau situasi yang diteliti.

Sumber data pada penelitian ini diperoleh dari deskripsi etnomatematika pada motif sulam ususdan dokumentasi berupa foto, buku, arsip budaya yang terkait dengan analisis etnomatematika pada motif sulam usus dalam bahasan geometri. Pada penelitian ini yang menjadi instrumen atau alat penelitian adalah peneliti itu sendiri. Peneliti kualitatif sebagai buman instrumen, berfungsi menetapkan fokus penelitian memilih informan sebagai data, dan membuat kesimpulan [15]. Adapun teknik yang peneliti gunakan dalam penelitian ini diantaranya wawancara, observasi, dokumentasi. Validitas pada penelitian ini menggunakan tringulasi sumber dan metode. Pemilihan tringulasi sumber dan metode ini didasarkan ketika hasil wawancara dengan pertanyaan yang sama tetapi menggunakan subjek yang berbeda untuk mendapatkan kecocokan dan kesimpulan jawaban dari hasil wawancara tersebut.

\section{HASIL PENELITIAN DAN PEMBAHASAN}

Sulam usus bukan hanya sekedar hasil kerajinan tradisional masyarakat Lampung lebih dari itu sulam usus digunakan untuk kerah perempuan, bebe, untuk busana adat, namun seiring berkembangnya zaman sulam usus mulai digunakan sebagai bahan pakaian, blus tradisional, kemeja laki-laki hingga gaun yang glamor. Sulam usus atau menurut bahasa tekstil disebut sebagai renda usus telah menjadi bagian dari tradisi kain Lampung sekitar abad ke-16 sampai abad ke-20.

Etnomatematika dengan unsur budaya yang bersifat fisik dapat ditemukan dari kerajinan asli tradisional Lampung yaitu sulam usus. Sulam usus ternyata menggambarkan suatu lambang, komsep, prinsip serta ketrampilan matematis yang diterapkan secara tidak sengaja oleh para pengrajin sulam usus. Terdapat dua macam hasil kerajinan sulam usus yang akan diteliti, diantaranya yaitu gaun dan kebaya sulam usus.

kajian etnomatematika pada taplak meja sulam usus khususnya mengenai geometri dan transformasi geometri. Dimensi satu sederhananya merupakan sebuah garis yang menghubungkan dua titik disebuah bidang yang memiliki sebuah ukuran yaitu panjang. 


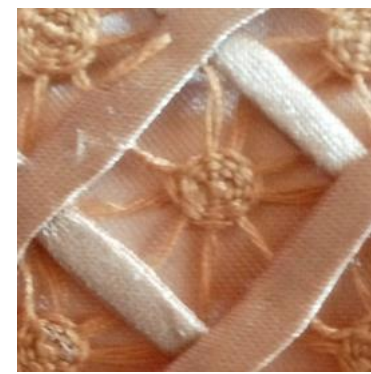

Gambar 1. Motif Belah Ketupat Sulam Usus

Gambar 1. adalah motif belah ketupat sulam usus yang muncul pada masa hindu budha dan menjadi baku dalam pembuatan motif sulam usus sampai saat, motif ini memiliki kesamaan dengan motif pada ragam hias di Indonesia. Ragam hias tersebut adalah Geometri Ornamen Toraja dalam kesenian toraja Sulawesi Tengah. Dilihat secara seksama bahwa dalam menempatkan benang dan pita usus yang membentuk motif belah ketupat ini menerapkan prinsip garis vertikal dan horizontal. Dalam elemen seni garis sendiri memiliki kemampuan untuk mengungkapkan suasana. Garis tegak lurus terbentuk dari garis vertikal dan horizontal pada benang sulam dan pita usus yang memenuhi pola bentuk usus.

Garis dikatakan sejajar jika garis yang berada pada satu bidang yang sama dan jika diperpanjang garis tersebut tidak saling berpotongan satu dengan yang lainnya. Pada motif belah ketupat yang terdapat pada taplak meja dan kebaya sulam usus terdapat konsep garis sejajar yang dibentuk dari pita sulam usu, yang akan dikaji lebih dalam menggunakan teorema berikut:

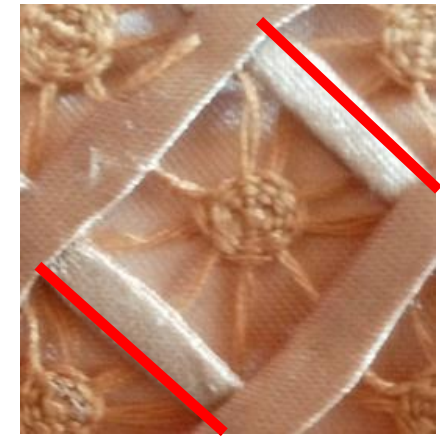

Gambar 2. Garis Sejajar Taplak Meja Sulam Usus

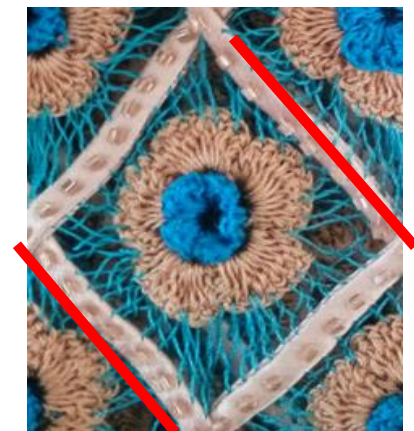

Gambar 3. Garis Sejajar Kebaya Sulam Usus

Geometri dimensi dua adalah bangun datar yang memiliki ukuran panjang dan lebar. Konsep geometri dimensi dua yang tedapat dalam motif sulam usus diantaranya : elips, dan belah ketupat. Keduanya merupakan simbol dari bentuk motif sulam usus, elips dan lingkaran berasal dari Taplak Meja Sulam Usus, dan kebaya sulam usus. Belah ketupat merupakan pola yang berasal dari motif geometris. Elips pada motif sulam usus merupakan transformasi dari motif eips yang di dalamnya terdapat jaring laba-laba yang terdapat pada hasil kerajinan Taplak Meja Sulam Usus, dan kebaya sulam usus. Belah ketupat. Gambar dibawah ini menunjukkan bahwa terdapat konsep belah ketupat yang terdapat pada kebaya sulam usus, dan taplak meja sulam usus.Belah ketupat adalah jajar genjang yang mempunyai dua sisi berdampingan yang kongruen. 


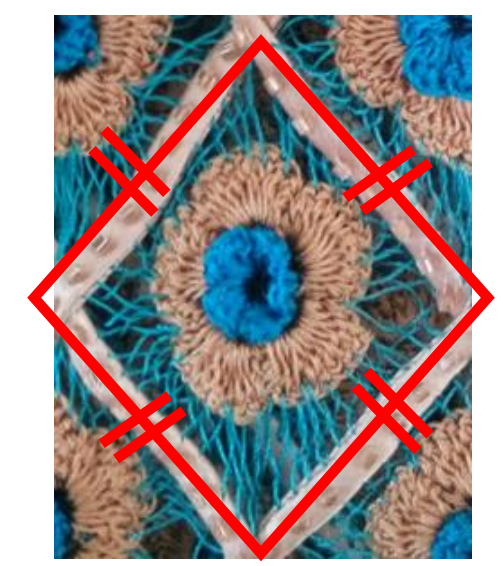

Gambar 4. Belah Ketupat Kebaya Sulam Usus

Terdapat konsep transformasi geometri dalam motif meander pada kebaya sulam usus, dan taplak meja sulam usus. Konsep matematika sebagai hasil aktivitas memola yang dapat diungkap dari motif tersebut diantaranya yaitu rotasi, dan refleksi. Kaidah ilmu matematika terkandung dalam sulam usus yang dibentuk dari setiap proses jelujur yang membentuk motif berdasarkan konsep transformasi geometri. Rotasi adalah memutar setiap titik pada bidang dengan menggunakan tititk pusat tertentu yang memiliki jarak sma dengan setiap titik yang diputar. Rotasi tidak mengubah uuran benda sama sekali. Rotasi juga diterapkan pada motif meander. Transformasi juga dapat membentuk perbesaran dan pengecilan yang sering disebut sebagai dilatasi. Faktor yang menyebabkan sebuah bangun mengalami perbesaran dan pengecilan dikarenakan adanya faktor dilatasi.

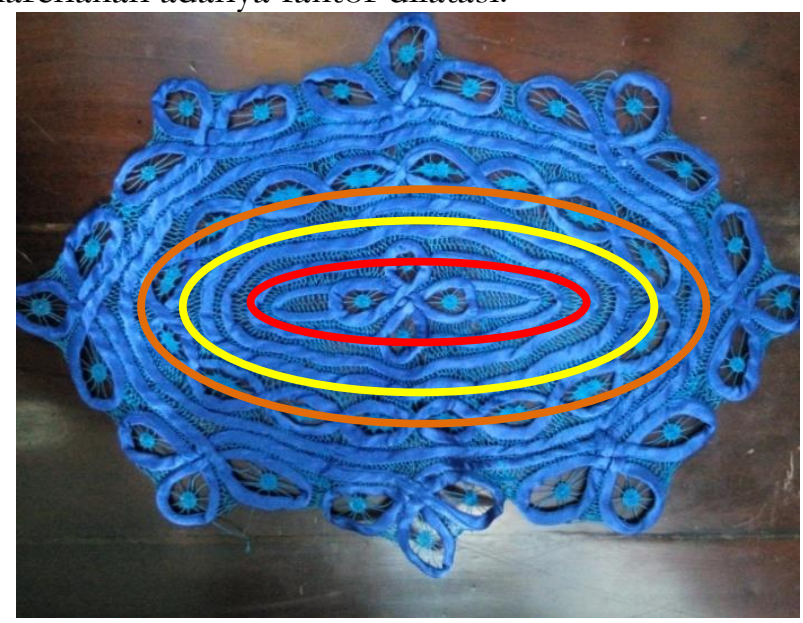

Gambar 5. Dilatasi motif elips

Gambar dibawah ini menunjukkan bahwa motif meander yang dipotong menggunakan sumbu X dan sumbu Y.

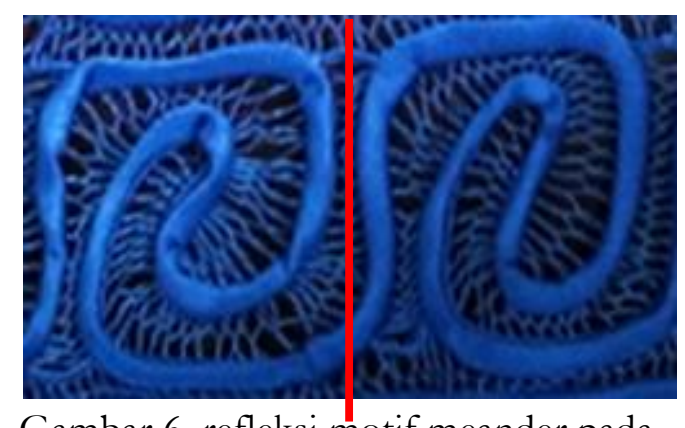

Gambar 6. refleksi motif meander pada taplak meja sulam usus

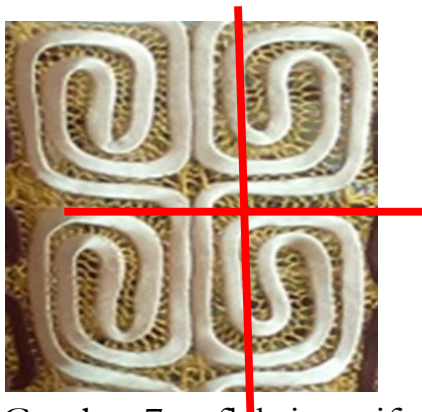

Gambar 7. refleksi motif meander pada kebaya sulam usus

Copyright (C) 2017, Numerical: Jurnal Matematika dan Pendidikan Matematika Print ISSN: 2580-3573, Online ISSN: 2580-2437 


\section{SIMPULAN DAN SARAN}

Berdasarkan hasil penelitian yang telah dilakukan dapat disimpulkan bahwa motif sulam usus mengandung makna matematika serta budaya atau sering disebut etnomatematika. Pada makna budaya terdapat kaitan antara sulam usus dengan budaya yang telah ada sebelumnya seperti adanya kaitan budaya antar kepercayaan hindu budha serta terdapat kesamaan motif serta ragam hias yang terdapat pada motif sulam usus dengan ragam hias yang ada di Indonesia. Kaitan antara motif sulam usus dengan matematika diantaranya terdapat unsur-unsur matematika diantaranya unsur geometri berupa geometri dimensi satu dan dimensi dua, dan geometri transformasi. Konsep geometri dimensi satu berupa garis sedangkan dimensi dua berupa bidang elips dan belah ketupat. Konsep geometri transformasi meliputi refleksi atau pencerminan, dalam hal pencerminan ini yang paling banyak terdapat pada sebuah motif yang terdapat dalam motif sulam usus, dilatasi atau pengecilan dan pembesaran, rotasi atau perputaran dan transalasi yaitu pergeseran. Selanjutnya, diharapkan pembuatan sulam usus dan motif yang ada di dalamnya dapat dijadikan referensi untuk pembelajaran karena didalamnya terdapat unsur-unsur matematika. Dalam perkembangan sulam usus lebih di eksplor kembali dan diperbanyak lagi pembukuan yang berkaitan tentang sulam usus, karena sulam usus merupakan warisan budaya asli Lampung.

\section{DAFTAR PUSTAKA}

[1] Putri, Linda Indiyarti, "Eksplorasi Etnomatematika Kesenian Rebana Sebagai Sumber Belajar Matematika Pada Jenjang MI,”J. Pendas, vol. 4, no. 1, 2017.

[2] Puspadewi, Kadek Rahayu and I. Gst Ngurah Nila Putra, "Etnomatematika di Balik Kerajinan Anyaman Bali," J. Mat., vol. 4, no. 2, pp. 80-89, 2014.

[3] Rosa, Milton and Daniel Clark Orey, "Ethnomathematics: the Cultural Aspects of Mathematics," Rev. Latinoam. Etnomatemática, vol. 4, no. 2, 2011.

[4] Koentjaraningrat, Pengantar Ilmu Antropologi. Jakarta: Rineka Cipta, 2009.

[5] Departemen Agama RI, Al-Hikmah Al-Qur'an dan Terjemahnya. Bandung: Diponegoro, 2010.

[6] Arfida, S. and Halim, S., "Perancangan Aplikasi Database Penjualan pada Kerajinan Sulam Usus Desa Margodadi Kecamatan Jati Agung Lampung Selatan," J. Teknol. Inf. Dan Bisnis Pengabdi. Masy. Darmajaya, vol. 1, no. 1, pp. 37-47, 2015.

[7] Putra, F. G., "Eksperimentasi Pendekatan Kontekstual Berbantuan Hands On Activity (HoA) Terhadap Kemampuan Pemecahan Masalah Matematik," Al-Jabar J. Pendidik. Mat., vol. 8, no. 1, pp. 73-80, 2017.

[8] Kadir, "Mengembangkan Norma Sosiomatematik (Sociomathematical Norms) Dengan Memanfaatkan Potensi Lokal Dalam Pembelajaran Matematika," J. Pendidik. Mat. Univ. Haluoleo Kendari, vol. 4, no. 1, Jun. 2008.

[9] Inda Rachmawati, "Eksplorasi Etnomatika Masyarakat Sidoarjo," Universitas Negeri Surabaya, Surabaya.

[10] Sardjana, A, Geometri Ruang. Jakarta: Universitas Terbuka., 2008.

[11] Greig, Jo., Tutor in a Book's Geometry, 2nd ed. California: The Geometry Store Berkeley, 2012. 
Numerical: Jurnal Matematika dan Pendidikan Matematika, Vol. 1 No. 2 Desember 2017, 87-96 Leni Zuni Isnawati, Fredi Ganda Putra

[12] Musser, G.L, Trimpe, L.E., and Maurer, V.R., College Geometry: A Problem-solving Approach with Applications. United States: Pearson Eduaction, Inc., 2008.

[13] Sabilirrosyad, "Ethnomathematics Sasak: Eksplorasi Geometri Tenun Suku Sasak Sukarara Dan Implikasinya Untuk Pembelajaran," J. Tatsqif J. Pemikir. Dan Penelit. Pendidik., vol. 14, no. 1, Jun. 2016.

[14] Sugiyono, Metode Penelitian Kuantitatif, Kualitatif dan R\&D. Bandung: Alfabeta, 2015.

[15] S. Arikunto, Prosedur Penelitian Suatu Pendekatan Praktik. Suharsimi: Rineka Cipta, 2013. 
Numerical: Jurnal Matematika dan Pendidikan Matematika, Vol. 1 No. 2 Desember 2017, 87-96 Leni Zuni Isnawati, Fredi Ganda Putra

[Halaman ini sengaja dikosongkan] 